\title{
Multiple whitish colonic sessile polyps in a patient with changes in bowel habit
}

\author{
Giuseppe Gizzi, ${ }^{1}$ Elena Sabattini, ${ }^{2}$ Lorenzo Fuccio ${ }^{3}$
}

\author{
${ }^{1} M F$ Toniolo Hospital, Bologna, \\ Italy \\ ${ }^{2}$ Unit of \\ Haemolymphopathology; \\ Department of Hematology \\ \& Oncology, S Orsola-Malpighi \\ Hospital, University of Bologna, \\ Bologna, Italy \\ ${ }^{3}$ Department of Medical and \\ Surgical Sciences (DIMEC), \\ Alma Mater Studiorum- \\ University of Bologna, \\ S Orsola-Malpighi Hospital, \\ University of Bologna, \\ Bologna, Italy
}

\section{Correspondence to} Dr Lorenzo Fuccio, lorenzofuccio@gmail.com

Accepted 22 June 2015

\section{DESCRIPTION}

A 71-year-old man presented with a 2-month change in bowel habit, with 2-3 bowel movements/ day with evacuation of fluffy faeces. A colonoscopy showed the presence of multiple small, whitish sessile polyps from the rectum up to the transverse; chromoendoscopy showed a decrease in the number of vascular network and irregular vessels (figure 1).

Histologically, a dense lymphocytic infiltrate of small cells was observed with a B-cell-derived phenotype (positive CD20 molecule), expression of the immunoglobulin superfamily receptor translocationassociated 1 (IRTA1) molecule, low proliferating index, and negativity for T-cell markers and cyclin D1 and SOX11 (figure 2); a diagnosis of extranodal peripheral B-cell lymphoma from marginal zone cells (mucosa-associated lymphoid tissue (MALT)-type) was made, which was also confirmed by the monoclonal rearrangement of immunoglobulin light chain genes at PCR analysis.

Colonic MALT-type lymphoma is very rare. The diffuse polypoid pattern seen at endoscopy is the most interesting feature of this case, as it is highly unusual in colonic MALT-type B-cell lymphoma. Such presentation more often relates to lymphoid follicular hyperplasia of the gastrointestinal mucosa or to a polypoid lymphomatosis sustained by a B-cell lymphoma of mantle cell origin. Both were excluded by immune morphology. Characteristic findings of intestinal lesions are a decrease in the number of vascular networks and the presence of irregular vessels on the surface of the epithelia. ${ }^{1}$

In our case, abdominal and chest CT scan showed neither abnormal lesions nor lymph node enlargement and the bone marrow biopsy was negative.

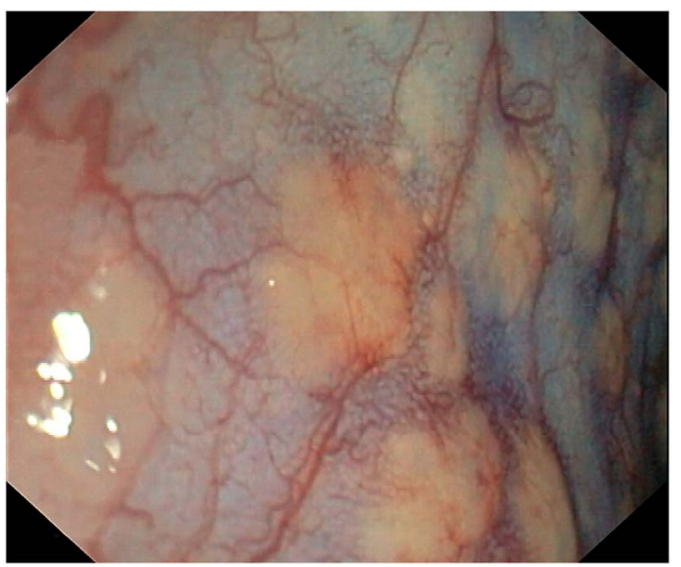

Sabattini E, Fuccio L. BMJ Case Rep Published online: [please include Day Month Year] doi:10.1136/bcr-2015211034

CrossMark
Figure 1 Colonoscopy: multiple small, whitish sessile polyps extending from the rectum up to the transverse. Chromoendoscopy with indigo carmine showing decreased number of vascular network and irregular vessels.

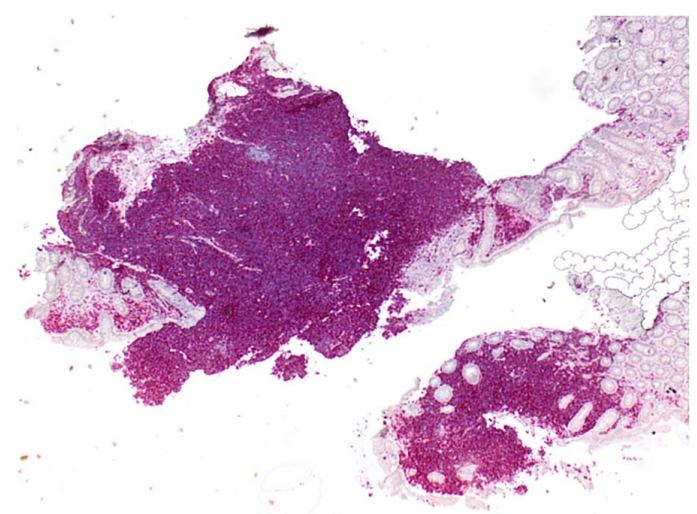

Figure 2 Histology: at immunohistochemistry, a diffuse positivity for the B-cell-associated molecule CD20 is observed (x10, Gill's haematoxylin).

Endoscopy, radiological procedures and immunological tests excluded synchronous localisation and associated diseases (ie, inflammatory and autoimmune diseases and chronic infections). The patient was informed of the indolent behaviour of the disease and a 'wait-and-see' strategy was chosen. A follow-up based on laboratory tests, abdominal ultrasound and colonoscopy was scheduled. Symptomatology was improved by the assumption of bulking agents and loperamide as needed. Three years after the diagnosis, no substantial changes were observed.

\section{Learning points}

Diffusion within the colon by a MALT-type lymphoma, in particular the involvement of only half of the colon, is extremely unusual.

- Endoscopists should be aware of this pattern; differential diagnosis includes follicular lymphoid hyperplasia and colonic mantle cell lymphoma.

- The diagnostic work-up should exclude the involvement of other sites and associated diseases (ie, inflammatory, autoimmune and infectious diseases).

\section{Competing interests None declared.}

Patient consent Obtained.

Provenance and peer review Not commissioned; externally peer reviewed.

\section{REFERENCE}

1 Fujiya M, Kashima S, Ikuta K, et al. Decreased numbers of vascular networks and irregular vessels on narrow-band imaging are useful findings for distinguishing intestinal lymphoma from lymphoid hyperplasia. Gastrointest Endosc 2014;80:1064-71. 


\section{Images in...}

Copyright 2015 BMJ Publishing Group. All rights reserved. For permission to reuse any of this content visit http://group.bmj.com/group/rights-licensing/permissions.

BMJ Case Report Fellows may re-use this article for personal use and teaching without any further permission.

Become a Fellow of BMJ Case Reports today and you can:

- Submit as many cases as you like

- Enjoy fast sympathetic peer review and rapid publication of accepted articles

- Access all the published articles

- Re-use any of the published material for personal use and teaching without further permission

For information on Institutional Fellowships contact consortiasales@bmjgroup.com

Visit casereports.bmj.com for more articles like this and to become a Fellow 